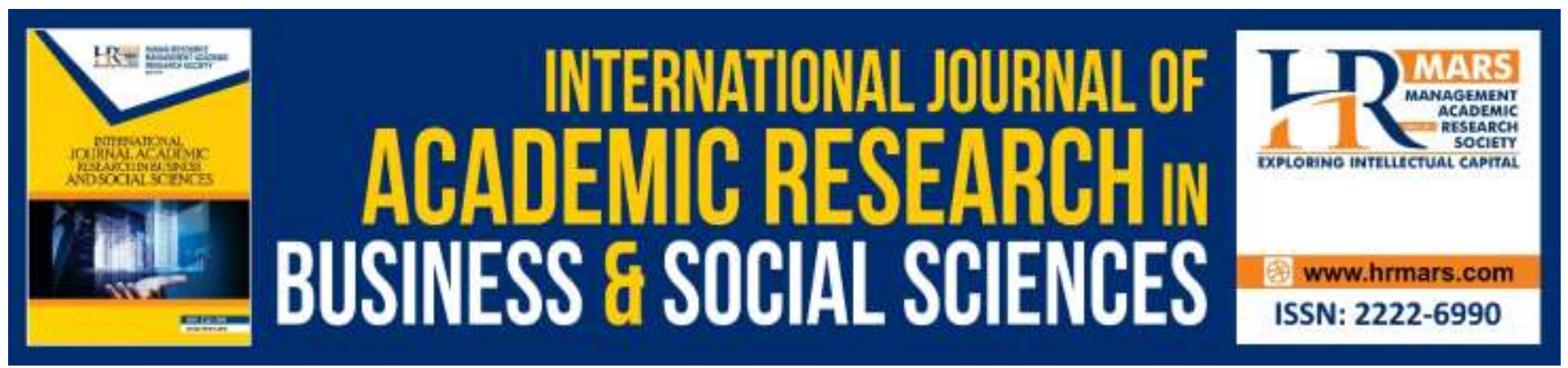

\title{
Evaluation Index System and Weight of NGO Evaluation: The Case of Yemen
}

\section{Mohammed Gamal Abdulkhaleq Al-khawlani, Fang Zhigeng}

To Link this Article: http://dx.doi.org/10.6007/JJARBSS/v9-i7/6098

DOI: 10.6007/IJARBSS/v9-i7/6098

Received: 22 May 2019, Revised: 27 June 2019, Accepted: 01 July 2019

Published Online: 30 July 2019

In-Text Citation: (Al-khawlani \& Zhigeng, 2019)

To Cite this Article: Al-khawlani, M. G. A., \& Zhigeng, F. (2019). Evaluation Index System and Weight of Ngo Evaluation: The Case of Yemen. International Journal of Academic Research in Business and Social Sciences, 9(7), 136-151

Copyright: (C) 2019 The Author(s)

Published by Human Resource Management Academic Research Society (www.hrmars.com)

This article is published under the Creative Commons Attribution (CC BY 4.0) license. Anyone may reproduce, distribute, translate and create derivative works of this article (for both commercial and non-commercial purposes), subject to full attribution to the original publication and authors. The full terms of this license may be seen at: http://creativecommons.org/licences/by/4.0/legalcode

Vol. 9, No. 7, 2019, Pg. 136 - 151

http://hrmars.com/index.php/pages/detail/IJARBSS

JOURNAL HOMEPAGE

Full Terms \& Conditions of access and use can be found at http://hrmars.com/index.php/pages/detail/publication-ethics 




\title{
Evaluation Index System and Weight of NGO Evaluation: The Case of Yemen
}

\author{
Mohammed Gamal Abdulkhaleq Al-khawlani, Fang Zhigeng \\ College of Economics and Management, Nanjing University of Aeronautics and Astronautics, 29 \\ Jiangsu Avenue, Nanjing, China \\ Email: Abukhawlan4@gmail.com,Zhigengfang@163.com
}

\begin{abstract}
Nongovernmental organizations have taken on eminent roles in delivering poverty reduction in all over the world. The objective of this research is to measure the accurate estimation of evaluation index system and weight of NGO evaluation for Yemen. This paper also focuses on methodological aspects which are much more than their infrastructure and the higher share of 'NGO in their total support in Yemen. We employed a mathematical composite indicator which combines various indicator in a systematic and comprehensive way. The results show that CO- NGO-Supported is positioned at top. With a normal average score of 0.65 among every single chosen nation, the NGO supported is positioned at second with an average composite record score is 0.62 . Supported farmer holds third position while non-supported is positioned No.4 among these types of farmers including different status such as Supported Farmer, Non- Supported Farmer, NGO-Supported, Non-NGOSupported and CO- NGO-Supported farmers in the Yemen. The study will provide valuable information towards policy makers and decision makers.
\end{abstract}

Keywords: Mathematical Composite Indicator, Index System, Weight, NGOs, Yemen

\section{Introduction}

Nongovernmental organizations have taken on distinguished roles in delivering environmental services in cities. The urban tree cover is one among the key urban environmental campaigns of the last decade, as dozens of cities round the world have enforced tree planting initiatives designed to extend their tree canopies (Ninnes Bert Jenkins, Hakena, \& Jenkins, 2017). These initiatives became the predominant urban strategy for mistreatment inexperienced infrastructure, or land and water resources, as a climate adaptation strategy. Trees contribute to inexperienced infrastructure in an exceedingly myriad of ways: they enhance air, water, and soil quality; mitigate water flows and surface temperatures; defend habitats; and supply a bunch of recreational, psychological, and assets advantages. However, the empirical findings will increase in urban tree (Lewis, 2007) and (EvansKent \& Bleiker, 2010) environmental sustainability and other benefits for society. 
INTERNATIONAL JOURNAL OF ACADEMIC RESEARCH IN BUSINESS AND SOCIAL SCIENCES

Vol. 9, No. 7, July, 2019, E-ISSN: 2222-6990 @ 2019 HRMARS

NGOs appear to be preferred as standard-setting partners by firms in various fields, such as sustainable, supply chain management, agriculture, packaging, fishing, labor issues, renewable energy, forest resources, health, and safety. The growing power of advocacy NGOs in setting international agendas, together with claims for their acceptability obligations and the voice accountability, brought financial issues of advocacy NGOs under public scrutiny (Zainon, Atan, Wah, \& Nam, 2011) and (Liverani, 2014).

Nongovernmental organizations became major players in operationalizing these campaigns. This serious reliance on civic partnerships has been thanks to an absence of monetary incentives for personal corporations and perceived self-interested involvement of civic stewards (Kumar Singh, 2013). The topical concentrate on civic leadership through partnership-led governance could be a common theme of climate governance. Environmental research scholars have for the most part examined these and alternative climate adaptation campaigns by using their developed methodology. (Mozaffari, 2015),(Cooke \& Brown, 2014), (Ikram, Mahmoudi, Shah, \& Mohsin, 2019), (Muhammad Mohsin, Zhang, Saidur, Sun, \& Sait, 2019) (lqbal et al., 2019) and (Tesseur, 2018). The work done by (Mendhe et al., 2018), and (Huang, Poh, \& Ang, 1995) provides a methodological insights regarding environmental structure and clean environmental characteristics (Asbahi et al., 2019). However, their work has also targeted on social networks as for the most part freelance of, and isolated from, broader trajectories of urban amendment. However, several criticize this networked governance exactly as a result of it underfunds public welfare services (which embody inexperienced infrastructure), whereas excessively action revenue-generating activities (Rafique \& Rehman, 2017). Distinguished environmental governance and climate adaptation students have drawn up this work to handle urban development trends in a by using specific method (Prince, Butler, \& Redman, 2017).

Various researchers have conducted the work related to the NGOs (Rana, 2012), (Phippard, 2018), (Osman \& Mekki, 2017), (Dasgupta, 2017), (Wesarat, Sharif, \& Majid, 2017), (Lopez, Smith, \& Pagnucco, 2007), (H. Zhou \& Pan, 2016) and (Sharma \& Bansal, 2017) while others work on related methodologies. Traditionally, the research scholars have been examined the performance of NGOs separately and they ignored the important and fundamental indicators which can represents the true picture of NGOs and their weighting criteria (Mahat \& Pokharel, 2017). They performed the partial view of the study while measuring the performance of the NGOs (Wunsch, 2016) and (Javier J. Hernández Acosta, 2016). Existing literature shows that none of the researchers combined the relevant and most comprehensive set of related indicators, nor did they use mathematical linear programming approach to measure the holistic performance of the NGOs. The previous studies objectives lacks the typical research questions including, critical assessment of the evaluation index system, evaluation of the weight of NGO performance and the measurement of weight allocation of NGO evaluation performance for the case of Yemen.

This research focus on the accurate estimation of composite list of evaluation index system and weight of NGO evaluation performance of Yemen. This paper also focus on methodological issues which are much more than their infrastructure and the higher share of 'NGO in their total support in the country. Therefore, to address this problem, we have constructed the comprehensive set of indicator system and employed a mathematical composite index that combines numerous aspects of an indicator in a systematic and transparent way. The composite index provides a pre-requisite 
understanding of energy efficiency challenges, energy supply profile and systematic assessment of international rankings. The study contained an empirical estimation of evaluation index system and weight of NGO evaluation performance of Yemen. The research objectives contain typical research questions including, (i) Critical assessment of the evaluation index system (ii) Assessment of weight of NGO evaluation performance (iii) Assessment of weight of NGO evaluation performance of Yemen. Reminder of the paper is organized as follows section: 2 define the background and literature review section 3 explains the methodology and assessment of interviews, section 4 explains the results and discussions whereas the at the end the section 5 conclude the paper and put forward the policy implications in order to create the easiness for the decision makers and policy makers.

\section{Literature Review}

NGOs are a primary institutional structure for delivering aid. Once touted as a curative, notably among the tutorial literature, NGOs have return to a lower place increasing scrutiny for his or her actions (K. Dupuy, Ron, \& Prakash, 2016). NGOs are recognized as powerful institutions which could have a considerable impact on the strategy that international-aid is gathered and assigned but together on the socio-economic establishments at intervals a country (Ninnes Bert Jenkins et al., 2017). Indeed, some have urged that NGOs are a component of the 'new imperialism' that will be a trendy form of domination and exploitation of developing countries. Throughout this context, international influence through political suggests that isn't the only form of management. Rather, multinational institutions and international NGOs can sort 'willing intermediaries' for exerting pressure. Analoui and Samour (2012) suggests that donors, administrative unit would possibly themselves be shaped by neo-liberal agendas, even have associate craving for supporting organizations that promote neo-liberal ideologies like "democratic liberalism and liberal democracy". Such neo-liberal problems, specifically in land, are shown to disempower beneficiaries by giving rise to agonistically logics and practices (Fleig et al., 2015).

(Kusman, 2015) argues that NGOs have given rise to "new publics (Gleiss, 2014) introduce utterly completely different categories of constituents that minimize sovereignty and challenge states as a result of the alone legitimate actors in international politics" (Dempsey, 2009) and (Brockington \& Scholfield, 2010).The 'divide' between 'Northern' (developed country) NGOs and their 'Southern' (developing country) counterparts has been documented. A multi-step method was wont to assess the interviews conducted for this analysis. for every interview, a close outline was ready in bullet kind of key points raised by the respondent. The semi-structured nature of the interviews resulted in an exceedingly very broad vary of topics. With the aim of compression this diversity of themes and opinions into a cryptic set of overarching topics, the K-J technique, created by Jiro Kawakita to prepare giant teams of opinions and information into broader classes, was wont to produce affinity diagrams . Consequently, the bullet points from the interview summaries were initial assembled into class clusters. This agglomeration method helped to spot themes of tangential or anecdotal relevancy to the explicit analysis queries, and these bullet points were put aside (Jamal \& Baldwin, 2019). Multiple iterations of the agglomeration and discarding method resulted in an exceedingly set of 5 overarching themes. Several of the clusters corresponded with the guiding queries developed for every cluster of respondents (see Supplementary materials), whereas others, like the role of social 
INTERNATIONAL JOURNAL OF ACADEMIC RESEARCH IN BUSINESS AND SOCIAL SCIENCES

Vol. 9, No. 7, July, 2019, E-ISSN: 2222-6990 @ 2019 HRMARS

media in pushing or preventative progress, and mismatches in scientific and legal experience resulted from this method (Peters, 2016).

\section{Methodology}

Composite indicators are synthetic indices or aggregates of all component indicators describing a multi-dimensional and often complex issue. DEA techniques to calculate composite indicators involving a range of different environmental and/or social issues. In essence, the transformation of the original formulation of DEA models into the mathematical programs needed to construct a composite indicator requires weighting, normalization and aggregation of various underlying indicators and sub-indicators. (Dočekalová \& Kocmanová, 2016) and (P. Zhou, Ang, \& Poh, 2007). Similarly the DEA there is another model which can provides the equations representing the DEA-like model used in the analysis and the DEA-like model can be used to aggregate the underlying indicators and sub-indicators.

As we argued that the DEA model can be used to construct the composite indicator for aggregation purpose due the virtue of DEA efficiency model, the DEA model and the DEA-like composite indicator model can be used to calculated: (i) standard efficiency; (ii) technical frontier; and (iii) and the overall efficiency. Overall efficiency, which consisted of a mean between the best and worst performance DMU's, was used for this analysis. The DEA model is usually a frontier of technical efficiency in order to assesses the inefficiency of a DMU building a frontier of units with the worst management practices (Hatefi \& Torabi, 2010). An conversation has been used from inputs to outputs and vice versa in the original DEA model for calculating the inefficiency frontier. The compound technical efficiency is an aggregate index corresponding to the composition between standard efficiency and inverted frontier efficiency and it needs good performance at the standard frontier and have not good performance at the inverted frontier for a DMU to have maximum compound technical efficiency. The literature in this line of research shows that the inverted efficiency was used for operational management analysis whereas the compound efficiency is used for greater rigor in evaluation, since the worst performers are also included in the metric. The authors had the support of the professional experts of the company for the design of the DEA model taking into account their experience, knowledge of the production process and condition of support in the development of research. There is a huge potential in the application of DEA in the process-specific manufacturing organizations in order to measure the efficiency of DMUs of products and services (Zeshan, 2011).

Here in our case the experts helped to collect data, define the attributes to be considered and define the variables to be used in the DEA-like composite indicator approach (U.S. Energy Information Administration, 2017). This procedure made it possible to identify the most important indicators aimed at restricting the analysis based on DEA like composite index As for dissimilarity is concerned with DEA and DEA-like composite indicator, the criterion used to determine the quantity of inputs and outputs was that the number of DMUs should be at least three times higher than the sum of inputs and outputs whereas there is no restrictions of underlying variables in order to measure the aggregate performance of the NGOs or any other organizations. Here NGOs are taken as a case study so our major concern will be remain about the performance of NGOs and the weight allocation of each indicator has been added to measure the performance. 
Furthermore, Stepwise indicator selection procedure is required to measure the performance score of DMUs in DEA like composite indicator while the DEA model requires the set of inputs and outputs to measure the efficiency of DMUs .Multiple criteria decision analysis (MCDA) and data envelopment analysis (DEA) are the widely used methods for aggregating $\mathrm{Cl}$ and weight allocation. We therefore used the methodology that is closely similar to aggregation purposes. The DEA as an aggregation model is written as follows:

$$
\begin{aligned}
& \mathrm{gI}_{\mathrm{i}}=\max \sum_{\mathrm{j}=1}^{\mathrm{n}} \mathrm{W}_{\mathrm{ij}}^{\mathrm{g}} \mathrm{I}_{\mathrm{ij}} \\
& \text { s.t } \quad \sum_{j=1}^{n} W_{i j}^{g} I_{k j} \leq 1 \quad k=1,2, \ldots, m \\
& \mathrm{~W}_{\mathrm{ij}}^{\mathrm{g}} \geq 0 \quad \mathrm{j}=1, \ldots, \mathrm{n}
\end{aligned}
$$

Model (1) is maximizing multiplier DEA model. The extended form of the model is (1) as follows:

$$
\begin{gathered}
b I_{i}=\min \sum_{j=1}^{n} W_{i j}^{b} I_{i j} \\
\text { s.t bI } I_{i}=\min \sum_{j=1}^{n} W_{i j}^{g} I_{k j} \geq 1, k=1,2, \ldots, m \\
W_{i j}^{b} \geq 0 \quad j=1 \ldots n
\end{gathered}
$$

Unlike model (1), model (2) searches for a' worst' set of weights to aggregate the sub-indicators into performance scores for each entity. Externally, with constant outputs and multiple inputs, Model (2) is like an input minimizing DEA multiplier model. Therefore, we combined the two indices in the following way in order to construct a $\mathrm{Cl}$ :

$$
\mathrm{CI}_{\mathrm{i}}(\lambda)=\lambda \frac{\mathrm{gI}_{\mathrm{i}}-\mathrm{gI}^{-}}{\mathrm{gI}^{*}-\mathrm{gI}^{-}}+(1-\lambda) \frac{\mathrm{bI}_{\mathrm{i}}-\mathrm{bI}^{-}}{\mathrm{bI}^{*}-\mathrm{bI}^{-}}
$$

where;

$$
\begin{aligned}
& \mathrm{gI}^{*}=\max \left\{\mathrm{gI}_{\mathrm{i}}, \mathrm{i}=1,2,3, \ldots, \mathrm{m}\right\} \\
& \mathrm{bI}^{*}=\max \left\{\mathrm{bI}_{\mathrm{i}}, \mathrm{i}=1,2,3, \ldots, \mathrm{m}\right\}
\end{aligned} \quad \mathrm{gI}^{-}=\min \left\{\mathrm{gI}_{\mathrm{i}}, \mathrm{i}=1,2,3, \ldots, \mathrm{m}\right\}
$$

And $0 \leq \lambda \leq 1$, is an adjusting parameter (P. Zhou et al., 2007). In model (3), we use linear scaling in min and max range by adjusting the parameter $\lambda$ that makes the two indices comparable in the range of $[0,1]$. After the selection of underlying indicators, the further step is the procedure of weight allocation of these indicators and then to collectively aggregate the indicators and sub-indicators needed to transform them into a composite index. The existing literature is evident that MCDA and DEA are two major methods being used for weighting, normalization and aggregation purpose (Peng Zhou \& Ang, 2008) however, the traditional tools used for aggregation purpose by MCDA are simple additive weighting (SAW) (Kang, 2002), weighted product (WP) (Ebert \& Welsch, 2004) and ideal distance weighting method (WDI) (Ju, Su, Zhou, Zhou, \& Zhang, 2015). Various scholars has used these aggregation tools to weight, normalize and then aggregate the underlying indicators and subindicators (Díaz-Balteiro \& Romero, 2004; P. Zhou, Ang, \& Poh, 2006). Zhou and Ang (P. Zhou \& Ang, 2009; P. Zhou, Ang, \& Zhou, 2010) shows that the WP method is considered as a more comprehensive tool for aggregation as compared to other MCDA tools due to the characteristics of less information loss (Hatefi \& Torabi, 2018). In the virtue of DEA and DEA-like composite indicator the weight restriction is a common practice in order to developing the composite index so consequently $\mathrm{U}_{\mathrm{k}}$ and 
INTERNATIONAL JOURNAL OF ACADEMIC RESEARCH IN BUSINESS AND SOCIAL SCIENCES Vol. 9, No. 7, July, 2019, E-ISSN: 2222-6990 @ 2019 HRMARS

$\mathrm{L}_{\mathrm{k}}$ are considered as the higher and lower weight while the values can be generated from expert consensus. It is a common practice and considered as an easier way to measure the weights through expert consensus see ref, (Cherchye, Lovell, Moesen, \& Van Puyenbroeck, 2007). Expert opinion consensus of our team members we allocate the $\mathrm{L}_{\mathrm{k}}=0.05$ and $\mathrm{U}_{\mathrm{k}}=0.20$, which shows the k-th sub-indicator can only contribute between $5 \%$ and $20 \%$ in developing the composite index score of NGOs in the Yemen. In essence, the fundamental criteria for input output selection recommended by DEA scholars in efficiency assessment, while DEA-like composite indicators are simply the normalization and aggregation of several underlying indicators. Likewise, vitality proficiency and ecological execution with extraordinary regard for low carbon discharges can improve vitality productivity and natural execution. The expansion in utilization has additionally prompted a $4 \%$ expansion in emanations (Mondal, Chowdhury, \& Basu, 2015). Our methodology is comparative as far as pointer determination, yet extraordinary regarding conglomeration technique. For example, they consolidated the various pointers in various gatherings and afterward asses the execution of those gatherings. While, we utilized numerical $\mathrm{Cl}$ for positioning and accumulation reason. Hertzberg discoveries bolster our contentions, as we guarantee that environmental change is increasingly powerless against ozone harming substance emanations and there is a need to change existing vitality structure into non petroleum derivatives (Shrestha \& Thygerson, 2019). The following indicators have been selected as an underlying variables, social safety net programs, various training facilities and soft loan schemes during the lean period, awareness campaign, introduction of new cropping patterns, various saving programs, introduction of different income generating activities and assistance upon them.

\section{Results and Discussions}

Table. 1 shows the descriptive statistics of the study.

Table:1 Descriptive Statistics

\begin{tabular}{llllllll}
\hline & Mean & Median & Maximum & Minimum & Std. Dev. & Skewness & Kurtosis \\
\hline SSP & 23.43 & 24.90 & 29.70 & 19.31 & 2.86 & -1.01 & 3.01 \\
TF & 7.92 & 2.78 & 3.36 & 2.04 & 0.50 & -0.46 & 1.96 \\
SL & 16.56 & 31.92 & 33.76 & 13.19 & 2.96 & -0.29 & -1.32 \\
AC & 32.10 & 31.83 & 38.75 & 26.341 & 3.48 & 0.211 & -0.96 \\
CP & 15.31 & 15.12 & 16.33 & 14.61 & 0.41 & 0.77 & 2.57 \\
SP & 13.58 & 12.50 & 18.63 & 11.75 & 17.26 & 0.33 & 1.42 \\
IG & 12.61 & 2.78 & 3.36 & 2.04 & 0.50 & -0.32 & 1.96 \\
\hline
\end{tabular}

Source: Author's own calculation by using E-Views 5

Where SSP stands for social safety net programs, TF shows various training facilities and soft loan schemes during the lean period, AC mean awareness campaign, CP represents the introduction of new cropping patterns, SP shows various saving programs, and IG shows the introduction of different income generating activities and assistance upon them.

Table 2 presents nations positioning as per in general composite Index score. Impact of various social protection interventions provided by NGOs such as social safety net programs, various training facilities and soft loan schemes during the lean period, awareness campaign, introduction of new cropping patterns, various saving programs, introduction of different income generating activities 
INTERNATIONAL JOURNAL OF ACADEMIC RESEARCH IN BUSINESS AND SOCIAL SCIENCES

Vol. 9, No. 7, July, 2019, E-ISSN: 2222-6990 @ 2019 HRMARS

and assistance upon them has been included in the study to measure the overall performance score. It can be seen that CO- NGO-Supported is positioned No. 1, with a normal average score of 0.65 among every single chosen nation. The greatest and least composite list score of CO- NGO-Supported amid the time of inquiry is 0.79 and 0.49 separately.

Table 2. Farmer ranking (in Yemen) according to overall composite Index score.

\begin{tabular}{llllll}
\hline Target Group & Score & Min & Max & Average & Rank \\
\hline Supported Farmer & 8.03 & 0.31 & 0.73 & 0.53 & 3 \\
Non- Supported Farmer & 7.31 & 0.29 & 0.72 & 0.48 & 4 \\
NGO-Supported & 9.34 & 0.48 & 0.74 & 0.62 & 2 \\
Non NGO-Supported & 5.88 & 0.26 & 0.58 & 0.39 & 5 \\
CO- NGO-Supported & 9.81 & 0.49 & 0.79 & 0.65 & 1 \\
\hline
\end{tabular}

$\mathrm{Cl}$ performance score has been generated by using DEA-Like composite indicator. In essence, it is necessary to mention that DEA can be used to measure the efficiency of possible set of DMU while the number of DMUs can be 1 to $n$ where $n=1,2,3, \ldots$, . There is no rule of thumb to restrict the number of DMUs in the virtue of DEA literature. Secondly, as we argued that the dimensionality problem arises in DEA based efficiency measurement whereas we have conducted an aggregation of various indicators through DEA-like composite indicator approach. Rather than DEA. DEA like composite indicator approach yielded the score in terms of benefit type indicator (larger the best) or in cost type indicator (smaller the best) whereas DEA approach yielded the performance score in the interval $[0,1]$. So there is no dimensionality problem in DEA-Like composite indicator.

Though, the NGO supported is positioned No. 2 with an average composite record score is 0.62 . The highest and least composite score of NGO-Supported is 0.74 and 0.48 respectively. Supported farmer holds third position while non-supported is positioned No.4 among these types of farmers including different status such as Supported Farmer, Non-Supported Farmer, NGO-Supported, Non NGOSupported and CO- NGO-Supported farmers in the Yemen. Table 1 shows that the positioning as per in general composite Index score of non-Supported farmer is positioned No. 4, with a normal average score of 0.48 while the highest and least composite list score is 0.72 and 0.29 separately. Likewise, NGO Supported and non-supported farmer populace is a lot littler than supported, which makes these nations as a superior entertainer arrangement incorporates 33-35\% decrease of the discharge force of GDP in 2030 and $40 \%$ power introduced limit from non-petroleum derivative assets. NonSupported farmer is positioned No. 4 with a normal composite Index score of 0.48 , its most extreme and least score is 0.72 and 0.29 separately due to the high ecological execution record. After that Non NGO-Supported is positioned at No.5 in this gathering with a total score of 5.88 and its most extreme score 0.58 while its base score is 0.26 whereas the average score is 0.39 .

Yemen economy is dependent on oil and the related a petroleum derivative economy and it is confronting vitality productivity weight in light of higher rate of vitality utilization. Currently the war with Saudi Arabia is experiencing vitality changes towards its infrastructure loss. Therefore the national and international NGOs are trying to serve the in order to better perform in the recovery of human being especially in the field of agriculture, medical and other rehabilitation process. Specially provisioning the help and support to the farmers. NGO receive nearly around the $20 \%$ of worldwide 
government funding in relation to humanitarian assistance, second only to United Nations' agencies. The full aid pool funded by the NGOs operates into billions of dollars, with an expected cost of aid through huge international NGOs. Paid the visible and expected cost of aid funding to NGOs, the governance infrastructures of NGOs are costly of deeper research. Mainly due to NGOs deals in big and huge stakeholder understanding in an environment with great political, economic and social schisms around the nature and form of international-aid funding.

Corporate governance is conceptually a building structure that creates a theoretical and practical framework for understanding, coordination and as a response mechanism to tackle the warning threats and challenges. Governance is instrumental in managing the organizational activities, as well as the interactions that occur with external stakeholders of the NGOs organization. How organizational governance pattern, structures shapes, and the relationships between them, has known importance on the emerging role of NGOs in the public community. It's mainly due to the increasing tension for NGOs to hold 'policy-advocacy' kind of work instead of the more 'traditional' development and humanitarian assistance roles they perform. The challenges and threats of NGOs working with governments have been well discussed. In particular, concerns NGO dependence on foreign-funding and foreign-aid logics of how to appropriate in a context. In this sense, it is important to note that accountability and governance is an important element within non-profit organizations such as MGOs

Changing structure in NGOs are very much subject to the political and ideological concerns that operates specific conceptions of how economic and social accountability must for that kind of organizations. These conceptions bring the governance within NGOs, basically influencing the nature of accounting data and information systems in the way that they capture, measure and report elements of organizational performance. It is obviously clear that government is the first regulatory authority that means governance needs to be conceptualized rather than misunderstanding and misconception from various perspective and it must be empirically examined through prepared analysis. Similarly, the explanations of governance shifts as well as the key stakeholders involved in the evaluation of NGOs. Organizational and management problems issues within NGOs are very less and few explored in the literature, although various studies have done a lot work on NGOs. There is also a perception that NGOs are primarily 'foreign facing' rather than directed at the needs of citizens within Yemen. The different types of NGOs, their different objectives, roles and the relationship with government and society have been studied by different researchers and they concluded that how they should be governed.

Generally NGOs acquire much more policy-advocacy activities rather than the traditional 'development' activities because these activities basically effects how NGOs create 'value and respect ' for stakeholders, to produce and generate support protection and authority, and how they operate projects in different environments and in different conditions. The different roles of NGO have been suggested to influence the expectations for the governance systems in order to ensure the good governance and ultimately good governance can leads towards productivity in the NGOs. The policyadvocacy role is usually acquired and adopt because the NGOs are expected to be more in the favor of a public interest.. Organizational association between NGOs, governments, and private firms are also becoming increasingly a great interest of the researcher. Some of them have researched and came to point that how business-NGO partnerships makes 'win-win' bonds and understandings 
INTERNATIONAL JOURNAL OF ACADEMIC RESEARCH IN BUSINESS AND SOCIAL SCIENCES

Vol. 9, No. 7, July, 2019, E-ISSN: 2222-6990 @ 2019 HRMARS

especially for business. Furthermore, the reliance on large-donor funding from primarily western backgrounds would attract the need for NGOs to reflect such ideologies and face the way NGOs are governed.

Results shows that quantity of land cultivation on the contrary, CO-NGO supported farmers contains a positive trend for land cultivation Similar trend was additionally found just in case of each variety of enterprises for the CO-NGO supported farmers than the non-supported one. It's clear that CONGO support contains an important impact on changes of agricultural enterprises. (Bryant \& Bryant, 2014) analyses the event of economic measures on a sample of agricultural enterprises within the European nation in 2006-2010. Compared to 2009, agricultural enterprises improved in 2010. Primarily, total production smart decline in 2009 accrued merely slightly and reached grade of 2006 within the average enterprise in Yemen.

In most of the cases, there's a positive and statistically important distinction over the years from 2005 to 2014 for CO-NGO supported farmers whereas for non-supported farmers, the results vary from year to year yet as enterprise to enterprise. The results instructed that the CO-NGO support and services had each short (2010 to 2017) and long-run (2014 to 2015) impacts on increasing agricultural enterprises of the GO-NGO supported farmers in charades, that is, the CO-NGO support and services created it doable for the households to complement their agricultural resources (K. E. Dupuy, Ron, \& Prakash, 2015). The high intensity of farming households had the most and mean crop intensity many thirty eight.5 and 27.5 for non-supported farmers and for CO-NGO supported farmers those were, 48.5 and 37.5 , severally that were beyond those of the low intensity households in rural areas. Majority (63.3\%) of the households belong to the low intensity class whereas the remaining thirty seven.7\% at high intensity households for non-supported farmers. just in case of CO-NGO supported farmers, majority (73.3\%) of the households belong to the high intensity class whereas the remaining $27 \%$ at low intensity households. (Atia \& Herrold, 2018) calculated the cropping intensification, the amount of technical potency of 252 maize-based farming households. Our results are similar to the Southern-Guinea Savannah (SGS) of Federal Republic of Nigeria and showed that the crop production intensity scores among the farming households ranged between five. 5 and 38.50 with a mean score of twenty three.

The high intensity farming households had the most and mean crop intensity many thirty eight.50 and 27.47 severally, that were beyond those of the low intensity households. (Schneiker, 2016) discovered that relationship of NGO-NGO with success convinced farmers by explaining the assorted blessings of land consolidation among them that accrued land and crop productivity astonishingly. The food security index and different connected food security measures like (Yu, Elleby, \& Zobbe, 2015), food insecurity gap/surplus index and head count quantitative relation are created severally for each non-supported and GO-NGO supported farmers. The food security index for food secured households was 1.13 for non-supported farmers and for GO-NGO supported farmers, it was 1.33 whereas for food insecure households, it was 0.84 and 0.80 , severally. supported the counseled daily calorie intake of two,122 kcal, it's ascertained that 57.0 percent of households were food secured just in case of non-supported farmers and for GO-NGO supported farmers it absolutely was 60. Average calorie intake of food secured households were two,390.55 kcal and a pair of,818.11 kcal for non-supported and GO-NGO supported farmers, severally that at beyond the national average calorie intake (i.e., 2,122 kcal). The food security gap or surplus index shows that the food secure households 
exceeded the food personal income by thirteen percent whereas food insecure households fell wanting the specified calorie intake by sixteen percent for non-supported farmers and for GO-NGO supported it absolutely was thirty three.0 and 20.0 percent, severally. (Asquith, Jack, Program, \& Bruijnzeel, 2011) dispensed a study on adapting associate experiential scale to live food insecurity in urban slum households of Asian nation. A nine-item experience-based food security scale was created by adapting the us home Food Security Survey Module, in step with that 15.4 percent of the households at food insecure. Findings additionally indicated that multi-sectoral interventions were needed to tackle the matter of urban food insecurity. (Rudasill \& Witt, 2016) assessed the contribution of improved rice varieties in financial condition reduction and food security in geographical area. A positive impact of improved varieties on food security and financial condition reduction was ascertained over the amount 2000-2014. additionally, the speed of adoption of those varieties accrued over these years and this increase was a lot of important when the 2008 food crisis. These trends might be increased by addressing production constraints and authorized seed bottlenecks. Also, the obtained results are in keeping with the results from previous studies by (Mohsin et al. 2018) and (Mohsin et al. 2018).

\section{Conclusion and Policy Implication}

We have built the structure of a marker framework and built up a composite list of evaluation index system and weight of NGO evaluation in a straightforward and precise path by utilizing DEA like numerical composite pointer. Results shows that the greatest and least composite list score of CONGO-Supported amid the time of inquiry is 0.79 and 0.49 separately. Though, the NGO supported is positioned No. 2 with an average composite record score is 0.62 . The highest and least composite score of NGO-Supported is 0.74 and 0.48 respectively. Supported farmer holds third position while non-supported is positioned No.4 among these types of farmers including different status such as Supported Farmer, Non- Supported Farmer, NGO-Supported, Non NGO-Supported and CO- NGOSupported farmers in the Yemen whereas the Index score of non-Supported farmer is positioned No. 4 , with a normal average score of 0.48 while the highest and least composite list score is 0.72 and 0.29 separately. Likewise, NGO Supported and non-supported farmer populace is a lot littler than supported, which makes these nations as a superior entertainer arrangement incorporates. Also, it can be reveals that non-Supported farmer is positioned No. 4 with a normal composite Index score of 0.48 , its most extreme and least score is 0.72 and 0.29 separately due to the high ecological execution record. After that Non NGO-Supported is positioned at No.5 in this gathering with a total score of 5.88 and its most extreme score 0.58 while its base score is 0.26 whereas the average score is 0.39 .

Policymakers should concentrate on improving its versatility on vitality circumstance to handle the climate occasions and catastrophic events, which thusly will enhance the vitality value. None of the nation has vitality productivity and vitality value circumstance and furthermore, they don't indicate driving job in its ecological execution, which additionally is by all accounts feeble yet at the same time Bhutan is positioned first among all group of nations. There is a need to guarantee stable vitality costs free of vitality request and supply, an endowment to substitute sustainable power source and built up a system of debilitating business sector and rivalry. These nations face serious issues in guaranteeing vitality supply after the enduring decrease in household fossil fuels. Even however, 
NGO-Supported has adjusted score in vitality proficiency yet it has a lower score in natural execution. From the perspective of policy, our paper briefly gives an understanding of how NGO governance is known and operationalized. This is important given the real time focus and scenarios on NGO accountability in the literature. Recently theoretical expositions have disputed that NGOs may have a main 'private authority', credibility and effect to 'change' other stakeholders.

This is the first exploratory paper into the system of NGO governance as its role in a context emerges more research is needed on multiple levels to test the positive and negative results of present governance regimes. In common way, the political landscape is mainly moving towards, with a number of governments all around the globe pursuing nationalistic policies that may lead constrain international-aid funding. Aid looks like aid funding further more could be reduced, worsening the financial constraints kept on NGOs operating in already challenging environments. That's why, further more case study research findings can elaborate on the new challenges NGOs are facing and, in particular, explains and finds what forms of NGO governance are evolving to respond to them.

\section{References}

Analoui, F., \& Samour, A. (2012). Strategic management: The case of NGOs in Palestine. Management Research Review, 35(6), 473-489. https://doi.org/10.1108/01409171211238253

Asbahi, A. A. M. H. Al, Gang, F. Z., Iqbal, W., Abass, Q., Mohsin, M., \& Iram, R. (2019). Novel approach of Principal Component Analysis method to assess the national energy performance via Energy Trilemma Index. Energy Reports, 5, 704-713. https://doi.org/10.1016/j.egyr.2019.06.009

Asquith, N., Jack, K., Program, S. S., \& Bruijnzeel, S. (2011). Do conservation projects work? How can NGOs and donors measure the impact of work on forest conservation and poverty? Ecosystem Services for Poverty Alleviation.

Atia, M., \& Herrold, C. E. (2018). Governing Through Patronage: The Rise of NGOs and the Fall of Civil Society in Palestine and Morocco. Voluntas, 29(5), 1044-1054. https://doi.org/10.1007/s11266-018-9953-6

Brockington, D., \& Scholfield, K. (2010). The work of conservation organisations in sub-Saharan Africa. Journal of Modern African Studies, 48(1), 1-33. https://doi.org/10.1017/S0022278X09990206

Bryant, R., \& Bryant, R. (2014). Mapping the Mission. In Nongovernmental Organizations in Environmental Struggles (pp. 164-201). https://doi.org/10.12987/yale/9780300106596.003.0007

Cherchye, L., Lovell, C. A. K., Moesen, W., \& Van Puyenbroeck, T. (2007). One market, one number? A composite indicator assessment of EU internal market dynamics. European Economic Review, 51(3), 749-779.

Cooke, D., \& Brown, T. P. (2014). Renewal in Samoa: Insights from life skills training. Pacific-Asian Education Journal, 26(1), 15-27. Retrieved from http://search.ebscohost.com/login.aspx?direct=true \&db=ehh\&AN=111655030\&site=ehostlive

Dasgupta, S. (2017). Experience or evidence: How do big conservation NGOs make decisions? Monga Bay News, pp. 1-15. 
INTERNATIONAL JOURNAL OF ACADEMIC RESEARCH IN BUSINESS AND SOCIAL SCIENCES

Vol. 9, No. 7, July, 2019, E-ISSN: 2222-6990 @ 2019 HRMARS

Dempsey, S. E. (2009). NGOs, Communicative Labor, and the Work of Grassroots Representation. Communication and Critical/Cultural Studies, 6(4), 328-345. https://doi.org/10.1080/14791420903348625

Díaz-Balteiro, L., \& Romero, C. (2004). In search of a natural systems sustainability index. Ecological Economics, 49(3), 401-405.

Dočekalová, M. P., \& Kocmanová, A. (2016). Composite indicator for measuring corporate sustainability. Ecological Indicators, 61, 612-623. https://doi.org/10.1016/J.ECOLIND.2015.10.012

Dupuy, K. E., Ron, J., \& Prakash, A. (2015). Who survived? Ethiopia's regulatory crackdown on foreign-funded NGOs. Review of International Political Economy, 22(2), 419-456. https://doi.org/10.1080/09692290.2014.903854

Dupuy, K., Ron, J., \& Prakash, A. (2016). What drives the crackdown on NGOs, and how can it be stopped?

Ebert, U., \& Welsch, H. (2004). Meaningful environmental indices: A social choice approach. Journal of Environmental Economics and Management, 47(2), 270-283. https://doi.org/10.1016/j.jeem.2003.09.001

Evans-Kent, B., \& Bleiker, R. (2010). NGOs and Reconstructing Civil Society in Bosnia and Herzegovina. International Peacekeeping, 10(1), 103-119. https://doi.org/10.1080/714002396

Fleig, L., Ngo, J., Roman, B., Ntzani, E., Satta, P., Warner, L. M., ... Brandi, M. L. (2015). Beyond single behaviour theory: Adding cross-behaviour cognitions to the health action process approach. British Journal of Health Psychology, 20(4), 824-841. https://doi.org/10.1111/bjhp.12144

Gleiss, M. S. (2014). How Chinese labour NGOs legitimize their identity and voice. China Information, 28(3), 362-381. https://doi.org/10.1177/0920203X14550376

Hatefi, S. M., \& Torabi, S. A. (2010). A common weight MCDA-DEA approach to construct composite indicators. Ecological Economics, 70(1), 114-120. https://doi.org/10.1016/j.ecolecon.2010.08.014

Hatefi, S. M., \& Torabi, S. A. (2018). A slack analysis framework for improving composite indicators with applications to human development and sustainable energy indices. Econometric Reviews, 37(3), 247-259. https://doi.org/10.1080/07474938.2016.1140286

Huang, J. P., Poh, K. L., \& Ang, B. W. (1995). Decision analysis in energy and environmental modeling. Energy, 20(9), 843-855. https://doi.org/10.1016/0360-5442(95)00036-G

Ikram, M., Mahmoudi, A., Shah, S. Z. A., \& Mohsin, M. (2019). Forecasting number of ISO 14001 certifications of selected countries: application of even GM $(1,1)$, DGM, and NDGM models. Environmental Science and Pollution Research. https://doi.org/10.1007/s11356-019-04534-2

Iqbal, W., Yumei, H., Abbas, Q., Hafeez, M., Mohsin, M., Fatima, A., ... Sohail, N. (2019). Assessment of Wind Energy Potential for the Production of Renewable Hydrogen in Sindh Province of Pakistan. Processes, 7(4), 196. https://doi.org/10.3390/pr7040196

Jamal, A., \& Baldwin, C. (2019). Angels of mercy or smiling western invaders? Community's perception of NGOs in northwest Pakistan. International Social Work, 62(1), 89-104. https://doi.org/10.1177/0020872817711239

Javier J. Hernández Acosta. (2016). The Role of Arts Organizations in Cultural Policy: The "Cultural Return" Analysis. INTERNATIONAL JOURNAL OF ARTS MANAGEMENT, $n^{\circ}$ Special(Latin 
INTERNATIONAL JOURNAL OF ACADEMIC RESEARCH IN BUSINESS AND SOCIAL SCIENCES

Vol. 9, No. 7, July, 2019, E-ISSN: 2222-6990 @ 2019 HRMARS

America), 56-69. Retrieved from https://www.gestiondesarts.com/en/the-role-of-artsorganizations-in-cultural-policy-the-cultural-return-analysis-pdf\#.XFrBB1xKiUk

Ju, K., Su, B., Zhou, D., Zhou, P., \& Zhang, Y. (2015). Oil price crisis response: Capability assessment and key indicator identification. Energy, 93. https://doi.org/10.1016/j.energy.2015.09.124

Kang, S. M. (2002). A sensitivity analysis of the Korean composite environmental index. Ecological Economics, 43(2-3), 159-174.

Kumar Singh, B. (2013). South Asia energy security: Challenges and opportunities. Energy Policy, 63, 458-468. https://doi.org/10.1016/J.ENPOL.2013.07.128

Kusman, A. P. (2015). The Politics of Good Governance in Post-Authoritarian East Java: Intellectuals and Local Power in Indonesia. Dissertation.

Lewis, D. (2007). Bringing in society, culture, and politics: Values and accountability in a Bangladeshi NGO. In Global Accountabilities: Participation, Pluralism, and Public Ethics (pp. 131-148). https://doi.org/10.1017/CBO9780511490903.009

Liverani, A. (2014). Civil Society in Algeria. Civil Society in Algeria. https://doi.org/10.4324/9780203894088

Lopez, G. A., Smith, J., \& Pagnucco, R. (2007). Globalizing Human Rights: The Work of Transnational Human Rights NGOs in the 1990s. Human Rights Quarterly, 20(2), 379-412. https://doi.org/10.1353/hrq.1998.0021

Mahat, K. B., \& Pokharel, B. B. (2017). Respondents wise Status of Non-Governmental Organizations (NGOs) of Karnali Zone Nepal. Journal of Advanced Academic Research, 2(1), 14-25. https://doi.org/10.3126/jaar.v2i1.16594

Mendhe, V. A., Mishra, S., Varma, A. K., Kamble, A. D., Bannerjee, M., Singh, B. D., ... Singh, V. P. (2018). Geochemical and petrophysical characteristics of Permian shale gas reservoirs of Raniganj Basin, West Bengal, India. International Journal of Coal Geology. https://doi.org/10.1016/j.coal.2018.01.012

Mohsin, M., Rasheed, A. K., \& Saidur, R. (2018). Economic viability and production capacity of wind generated renewable hydrogen. International Journal of Hydrogen Energy, 43(5), 2621-2630. https://doi.org/10.1016/j.ijhydene.2017.12.113

Mohsin, M., Zhang, J., Saidur, R., Sun, H., \& Sait, S. M. (2019). Economic assessment and ranking of wind power potential using fuzzy-TOPSIS approach. Environmental Science and Pollution Research. https://doi.org/10.1007/s11356-019-05564-6

Mohsin, M., Zhou, P., Iqbal, N., \& Shah, S. A. A. (2018). Assessing oil supply security of South Asia. Energy, 155, 438-447. https://doi.org/10.1016/j.energy.2018.04.116

Mondal, D., Chowdhury, S., \& Basu, D. (2015). Role of Non Governmental organization in Disaster Management. Research Journal of Agricultural Sciences, 6, 1485-1489.

Mozaffari, A. (2015). The heritage NGO: A case study on the role of grass roots heritage societies in Iran and their perception of cultural heritage. International Journal of Heritage Studies, 21(9), 845-861. https://doi.org/10.1080/13527258.2015.1028961

Ninnes Bert Jenkins, P., Hakena, H., \& Jenkins, B. (2017). NGOs and Post-Conflict Recovery : The Leitana Nehan Women?s Development Agency, Bougainville. NGOs and Post-Conflict Recovery: The Leitana Nehan Women?s Development Agency, Bougainville. https://doi.org/10.26530/oapen_459395 
INTERNATIONAL JOURNAL OF ACADEMIC RESEARCH IN BUSINESS AND SOCIAL SCIENCES

Vol. 9, No. 7, July, 2019, E-ISSN: 2222-6990 @ 2019 HRMARS

Osman, R. bt. A. H., \& Mekki, A. (2017). The Tiger and the Terrorist: How Malaysian NGOs deal with Terrorism. Intellectual Discourse, 25(2), 297-319. Retrieved from

http://search.ebscohost.com/login.aspx?direct=true\&db=aph\&AN=127115273\&amp;lang=ja\& site $=$ ehost-live

Peters, R. W. (2016). Local in Practice: Professional Distinctions in Angolan Development Work. American Anthropologist, 118(3), 495-507. https://doi.org/10.1111/aman.12597

Phippard, T. (2018). Medicine in the Meantime: The Work of Care in Mozambique. Canadian Journal of African Studies / Revue Canadienne Des Études Africaines, 53(1), 175-177. https://doi.org/10.1080/00083968.2018.1520791

Prince, R. C., Butler, J. D., \& Redman, A. D. (2017). The Rate of Crude Oil Biodegradation in the Sea. Environmental Science and Technology, 51(3), 1278-1284.

https://doi.org/10.1021/acs.est.6b03207

Rafique, M. M., \& Rehman, S. (2017). National energy scenario of Pakistan - Current status, future alternatives, and institutional infrastructure: An overview. Renewable and Sustainable Energy Reviews. https://doi.org/10.1016/j.rser.2016.11.057

Rana, S. (2012). Frontline Youth Work with Street Children and Youth in Nepal: Edge Work, Boundary Work, Hard Work. ProQuest Dissertations and Theses. Retrieved from http://search.proquest.com/docview/1283379289?accountid=13963\%5Cnhttp://resolver.ebsc ohost.com/openurl?ctx_ver=Z39.88-2004\&ctx_enc=info:ofi/enc:UTF-

8\&rfr_id=info:sid/Sociology+Database\&rft_val_fmt=info:ofi/fmt:kev:mtx:dissertation\&rft.genr $\mathrm{e}=$ dissertations $+\% 26$

Rudasill, L. M., \& Witt, S. W. (2016). Non-Governmental Organizations and Information. In Encyclopedia of Library and Information Sciences, Third Edition (pp. 3916-3923). https://doi.org/10.1081/e-elis3-120043551

Schneiker, A. (2016). NGO-NGO Relations. In Palgrave Handbook of Inter-Organizational Relations in World Politics (pp. 319-336). https://doi.org/10.1057/978-1-137-36039-7_15

Sharma, G., \& Bansal, P. (2017). Partners for Good: How Business and NGOs Engage the Commercial-Social Paradox. Organization Studies, 38(3-4), 341-364. https://doi.org/10.1177/0170840616683739

Shrestha, S., \& Thygerson, S. M. (2019). Brick Kilns of Nepal: A Non-Governmental Organization Perspective. Open Journal of Safety Science and Technology, 9(1), 1-6. https://doi.org/10.4236/ojsst.2019.91001

Tesseur, W. (2018). Researching translation and interpreting in Non-Governmental Organisations. Translation SpacesTranslation Spaces. A Multidisciplinary, Multimedia, and Multilingual Journal of Translation, 7(1), 1-19. https://doi.org/10.1075/ts.00001.tes

U.S. Energy Information Administration. (2017). International Energy Outlook 2017. International Energy Outlook. https://doi.org/www.eia.gov/forecasts/ieo/pdf/0484(2016).pdf

Wesarat, P., Sharif, M. Y., \& Majid, A. H. A. (2017). A Qualitative Investigation on Work in NGOs: The Case of Songkhla Province of Thailand. International Journal of Human Resource Studies, 3(2), 79. https://doi.org/10.5296/ijhrs.v3i2.3873

Wunsch, N. (2016). Coming full circle? Differential empowerment in Croatia's EU accession process. Journal of European Public Policy, 23(8), 1199-1217. 
INTERNATIONAL JOURNAL OF ACADEMIC RESEARCH IN BUSINESS AND SOCIAL SCIENCES

https://doi.org/10.1080/13501763.2016.1186207

Yu, W., Elleby, C., \& Zobbe, H. (2015). Food security policies in India and China: implications for national and global food security. Food Security, 7(2), 405-414.

https://doi.org/10.1007/s12571-015-0432-2

Zainon, S., Atan, R., Wah, Y. B., \& Nam, R. Y. T. (2011). Institutional donors ' expectation of information from the Non-Profit Organizations ( NPOs ) reporting : A pilot survey. International NGO Journal, 6(8), 170-180. https://doi.org/10.5897/NGOJ11.013

Zeshan, M. (2011). Renewable and Nonrenewable Energy Consumption, Real GDP and CO2 Emissions Nexus: A Structural VAR Approach in Pakistan.

Zhou, H., \& Pan, Q. (2016). Information, Community, and Action on Sina-Weibo: How Chinese Philanthropic NGOs Use Social Media. Voluntas, 27(5), 2433-2457. https://doi.org/10.1007/s11266-016-9685-4

Zhou, P., \& Ang, B. W. (2008). Indicators for assessing sustainability performance. In Handbook of performability engineering (pp. 905-918). Springer.

Zhou, P., \& Ang, B. W. (2009). Comparing MCDA aggregation methods in constructing composite indicators using the Shannon-Spearman measure. Social Indicators Research, 94(1), 83-96. https://doi.org/10.1007/s11205-008-9338-0

Zhou, P., Ang, B. W., \& Poh, K. L. (2006). Comparing aggregating methods for constructing the composite environmental index: An objective measure. Ecological Economics, 59(3), 305-311. https://doi.org/10.1016/J.ECOLECON.2005.10.018

Zhou, P., Ang, B. W., \& Poh, K. L. (2007). A mathematical programming approach to constructing composite indicators. Ecological Economics, 62(2), 291-297. https://doi.org/10.1016/j.ecolecon.2006.12.020

Zhou, P., Ang, B. W., \& Zhou, D. Q. (2010). Weighting and aggregation in composite indicator construction: A multiplicative optimization approach. Social Indicators Research, 96(1), 169181. https://doi.org/10.1007/s11205-009-9472-3 